\title{
Studi Elevasi Dasar Perairan untuk Penentuan Lantai Dermaga Pelabuhan di Pelabuhan TPI Wonokerto Kabupaten Pekalongan
}

\author{
Samudera Adi Bramastya*, Jarot Marwoto, Purwanto, Warsito Atmodjo dan \\ Elis Indrayanti
}

\author{
Departemen Oseanografi, Fakultas Perikanan dan Ilmu Kelautan, Universitas Diponegoro \\ Jl. Prof. H. Sudarto, SH, Tembalang Semarang. 50275 Telp/fax (024)7474698
}

Email : samuderaadibramastya@ students.undip.ac.id

\begin{abstract}
Abstrak
Wilayah Kabupaten Pekalongan secara administratif berbatasan dengan Sebelah Utara Kota Pekalongan dan Laut Jawa. Wilayah Kabupaten Pekalongan merupakan tempat berbagai aktivitas salah satunya aktifitas pelabuhan perikanan. Perlu dilakukannya revitalisasi pelabuhan dari analisis pasang surut. Penelitian ini bertujuan untuk mengetahui karakteristik pasang surut, meramalkan pasang surut 5 tahun kedepan, analisis kedalaman kolam pelabuhan, dan analisis ketinggian lantai dermaga. Data yang diambil adalah data kedalaman dan data pasang surut realtime 15 piantan untuk mengetahui tipe pasang surut dan peramalan pasang surut sedangkan untuk mengetahui kondisi kolam pelabuhan dan lantai dermaga menggunakan data pasang surut yang telah diolah. Analisa pasang surut menggunakan metode Admiralty dan Worldtide diperoleh tipe pasang surut di perairan TPI Wonokerto yaitu campuran condong harian tunggal dan peramalan selama 5 tahun kedepan. Analisis kolam pelabuhan menggunakan perhitungan LLWL didapatkan nilai sebesar 2,05 m untuk kapal 10 GT dan dinyatakan layak untuk kapal bersandar. Sedangkan untuk lantai dermaga diperoleh jeda antara HHWL dan lantai dermaga sebesar $33 \mathrm{~cm}$ untuk metode Admiralty dan $26 \mathrm{~cm}$ untuk metode Worldtide sehingga dapat dikatan dermaga tersebut layak untuk tempat bersandar kapal.
\end{abstract}

Kata kunci : Pasang Surut, Kolam Pelabuhan, TPI Wonokerto

\begin{abstract}
Pekalongan Regency is administratively bordered by the North of Pekalongan City and the Java Sea. The Pekalongan Regency area is a place for various activities, one of which is fishing port activities. It is necessary to revitalize the port from the tidal analysis. The purpose of this study is to determine the characteristics of the tides, predict the tides for the next 5 years, analyze the depth of the harbor pool, and analyze the height of the pier floor. The data taken are depth data and real-time tidal data 15 piantan to determine the type of tide and tidal forecasting while determining the condition of the harbor pool and pier floor using tidal data that has been processed. Tidal analysis using the Admiralty and Worldwide methods obtained tidal types in the waters of TPI Wonokerto, namely a mixture of single daily skew and forecasting for the next 5 years. Analysis of the port pool using the LLWL calculation obtained a value of $2.05 \mathrm{~m}$ for a $10 \mathrm{GT}$ ship and was declared feasible for a berthed ship. As for the pier floor, the gap between the HHWL and the pier floor is $33 \mathrm{~cm}$ for the Admiralty method and $26 \mathrm{~cm}$ for the World tide method so that it can be said that the pier is suitable for a place to dock ships.
\end{abstract}

Keywords : Tidal Analisyst, Harbour Resevoir, TPI Wonokerto

\section{PENDAHULUAN}

Wilayah Kabupaten Pekalongan merupakan perpaduan antara wilayah dataran rendah di bagian utara dan dataran tinggi di bagian selatan yang termasuk dalam kawasan dataran tinggi Dieng. Kawasan dataran tinggi di kabupaten ini berada pada 1.294 meter dari permukaan laut. Kabupaten Pekalongan secara administratif berbatasan dengan Sebelah Utara Kota Pekalongan dan Laut Jawa, Sebelah Timur Kabupaten Batang dan Kota Pekalongan, Sebelah Selatan Kabupaten Banjarnegara dan Kabupaten Purbalingga dan Sebelah Barat Kabupaten Pemalang. Wilayah kabupaten pekalongan utara merupakan tempat berbagai aktivitas salah satunya aktifitas perikanan di muara Sungai Bedahan (Mustofa et al, 2018)

Sungai Bedahan merupakan salah satu contoh sungai besar di Kab. Pekalongan yang juga merupakan titik temu antara Sungai Sragi Baru dengan Sungai Mrican sehingga pada muara sungai 
Bedahan terdapat Tempat Pelelangan Ikan (TPI) yakni TPI Wonokerto daerah tersebut juga merupakan tempat perlintasan kapal-kapal nelayan karena terdapat sebuah kolam pelabuhan yang dapat dibilang padat akan kegiatannya . Menurut Mustofa et al (2018) Muara dari Sungai Bedahan biasanya dimanfaatkan untuk berbagai bidang yakni memancing, penjemuran udang rebon, pembangunan tambak, dan irigasi oleh penduduk setempat. Padatnya aktivitas dari warga setempat permasalahan yang timbul pada daerah tersebut beragam layaknya limbah pabrik, intrusi air laut, sedimentasi pada muara dan Banjir rob.

Pada perairan TPI Wonokerto terdapat banyak tanaman mangrove dan tambak yang berada di bagian sisi kanan dan kiri Sungai Bedahan sampai menuju muara di TPI Wonokerto, dengan kedalaman maksimal rata - rata Sungai Bedahan mencapai sekitar 3 meter untuk melihat karateristik dan menentukan elevasi dermaga pada perairan TPI Wonokerto masih cukup aman atau perlu dilakukan pengembangan pelabuhan lebih lanjut sebagai tempat sandar kapal dan tempat perlintasan kapal nelayan, dalam hal ini fungsi pasang surut dalam bidang oseanografi sangat dibutuhkan sekali khususnya, dimana hal tersebut bermanfaat bagi banyak pihak terutama nelayan dan juga pemegang keputusan dalam mengelola perencanaan pengembangan kawasan pelabuhan.

\section{MATERI DAN METODE}

Penelitian berlangsung pada bulan Juni 2020 selama 15 hari di perairan TPI Wonokerto, Kabupaten Pekalongan, Jawa Tengah. Materi yang digunakan dalam penelitian ini dibagi menjadi dua data yaitu data primer dan data sekunder. Adapun data primer yang digunakan yaitu data yang didapatkan dari pengukuran lapangan berupa data pasang surut yang diperoleh melalui instrumen kelautan Tide Logger selama 15 piantan. Sedangkan untuk data sekunder meliputi prakiraan kedalaman kolam pelabuhan yang diukur menggunakan Single Beam Echosounder, Peta Rupa Bumi Indonesia lembar Pekalongan skala 1 : 25.000, dan Citra Satelit Google Earth tahun 2020.

Metode yang digunakan dalam penelitian ini adalah metode kuantitatif yang merupakan metode penelitian dengan memperoleh data yang berbentuk angka atau data kualitatif yang berupa angka (Sugiyono, 2006). Penentuan lokasi sampling menggunakan metode yang dinamakan Purposive Sampling Method yang berarti menentukan lokasi pengambilan sampel berdasarkan pertimbangan - pertimbangan tertentu. Penentuan lokasi pengamatan dilakukan berdasarkan kondisi yang dapat mewakili kondisi secara keseluruhan daerah dan memperhatikan kemudahan pencapaian (Sugiyono, 2012).

\section{Pasang Surut}

Pengukuran pasang surut dilakukan selama 15 hari dengan interval 1 jam menggunakan tide logger yang di rekam dengan prinsip logging secara real time dan otomatis, termasuk koordinat pemasangan alat yang dianggap sudah mewakili kondisi perairan Kota Pekalongan dengan pertimbangan alat pengukur selalu terendam saat pasang tertinggi dan surut terendah. Alat ini dipasang pada tongkat yang arahnya tegak lurus dengan permukaan air

Hasil yang diperoleh diolah menggunakan metode Admiralty untuk mengetahui nilai MSL, HHWL, LLWL, dan nilai Formzhal dengan demikian karakteristk pasang surut pada perairan TPI Wonokerto dapat diketahui. Sedangkan untuk metode pasang surut digunakan metode Worldtides dilakukan peramalan pasang surut selama 5 tahun dari tahun 2022 hingga 2026 untuk mengetahui HHWL tertinggi dan LLWL terendah selama periode 5 tahun. Peramalan Worldtide kemudian di verifikasi dengan data pasang surut lapangan. Berdasarkan perbandingan data pasang surut lapangan dan data pasang surut Worldtide didapatkan verifikasi antara data pasang surut lapangan dengan Worldtide diperoleh nilai sebesar 0,299. Menurut Atmodjo (2011) dalam Candrasari et al. (2015) verifikasi suatu model dapat diterima kebenarannya apabila nilai MSE masih berada didalam ambang batas $40 \%(0,4)$. Dengan hal itu metode peramalan pasang surut dengan Worldtides dapat dilanjutkan. 


\section{Kedalaman Kolam Pelabuhan}

Menurut Triadmodjo (1998) kedalaman kolam pelabuhan perairan dapat dihitung dengan menggunakan Chart Datum Low Water Spring (LWS) atau menggunakan Lowest Low Water Level (LLWL). Untuk mendapatkan kondisi kedalaman alur pelayaran dan kedalaman kolam pelabuhan yang ideal, digunakan dasar perhitungan dengan formula sebagai berikut:

$$
\mathrm{H}=\mathrm{d}+\mathrm{s}+\mathrm{c}
$$

Dimana :

$\mathrm{H}=$ Kedalaman alur pelayaran (m)

$\mathrm{d}=$ Draft kapal

$\mathrm{s}=$ squat atau Gerak vertikal kapal karena gelombang (toleransi max $0,5 \mathrm{~m}$ )

$\mathrm{c}=$ Clearance atau Ruang kebebasan bersih minimum $0,5 \mathrm{~m}$

Ruang kebebasan bruto adalah jarak antara sisi bawah kapal dan elevasi dasar nominal, pada draft kapal maksimum yang diukur pada air diam. Ruang ini terdiri dari ruang gerak vertikal kapal karena pengaruh glombang dan squat dan ruang kebebasan bersih ruang kebebasan bersih adalah ruang minimum yang tersisa antara sisi terbawah kapal dan elevasi dasar alur nominal kapal, pada kondisi kapal bergerak dengan kecepatan penuh dan pada gelombang pada angin terbesar. Ruang kebebasan bersih minimum adalah 0,5 meter untuk dasar laut berpasir dan 1 meter dasar perairan karang.

Menurut Dinas Kelautan dan Perikanan Kabupaten Pekalongan kapal terbesar yang bersandar pada dermaga TPI Wonokerto adalah $10 \mathrm{GT}$, pada umumnya nelayan disana mayoritas menggunakan kapal ikan berbobot 3 dan 5 GT.

\section{Ketinggian Lantai Dermaga}

Data pasang surut yang telah diolah menghasilkan nilai komponen pasang surut yang akan digunakan untuk mencari nilai HHWL yang berguna untuk melakukan perhitungan ketinggian dermaga. Tinggi lantai dermaga dihitung dalam keadaan pada saat air pasang. Menurut Standar Kriteria Desain untuk Pelabuhan di Indonesia, Januari 1984, ditentukan bahwa jarak antara lantai dermaga dengan HHWL dengan memperhitungkan besarnya pasang surut air laut dan kedalaman air rencana seperti ketentuan pada tabel dibawah

Tabel 1. Elevasi Aman Lantai Dermaga Diatas HHWL

\begin{tabular}{|c|c|c|}
\hline $\begin{array}{c}\text { Pelabuhan } \\
\text { dengan : }\end{array}$ & $\begin{array}{c}\text { Tunggang } \\
\text { Pasut } \\
\text { 3atau lebih }\end{array}$ & $\begin{array}{c}\text { Tunggang } \\
\text { Pasut kurang } \\
\text { dari 3 m }\end{array}$ \\
\hline $\begin{array}{c}\text { Kedalaman air } \\
4,5 \text { m atau } \\
\text { lebih }\end{array}$ & $0,5-1,5 \mathrm{~m}$ & $1,0-2,0 \mathrm{~m}$ \\
\hline $\begin{array}{c}\text { Kedalaman air } \\
\text { kurang dari } 4,5 \\
\mathrm{~m}\end{array}$ & $0,3-1,0 \mathrm{~m}$ & $0,5-1,5 \mathrm{~m}$ \\
\hline
\end{tabular}

Berdasarkan ketentuan Tabel 4 diatas menurut Wijaya et al., (2017) elevasi dermaga dapat ditentukan dengan menggunakan rumus berikut:

$$
\mathrm{H}=\mathrm{HHWL}+(\text { Clearance })
$$




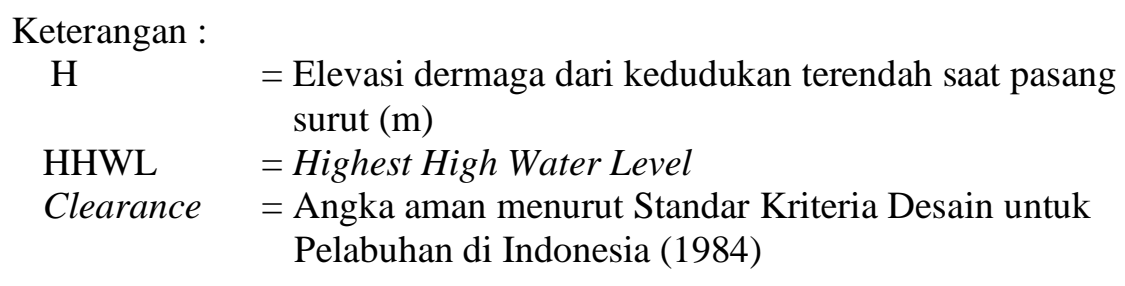

Menurut pengamatan pasang surut yang dilakukan, data ketinggian dermaga pada TPI berdasarkan Dinas Kelautan dan Perikanan Kabupaten Pekalongan adalah $400 \mathrm{~cm}$ dan memiliki kedalaman perairan pada saat pasang tertinggi sebesar 2,09 $\mathrm{m}$. Sedangkan besar tunggang pasut yang terjadi di perairan TPI Wonokerto tidak lebih dari 3 meter. Sehingga menurut beberapa ketentuan tersebut dapat diketahui bahwa nilai Clearance yang digunakan adalah $1,5 \mathrm{~m}$ atau 5 feet.

\section{HASIL DAN PEMBAHASAN}

\section{Pasang Surut Metode Admiralty}

Data pasang surut pada daerah penelitian adalah data realtime yang diambil pada bulan Juni 2020 menggunakan instrumen RBR Tide logger selama 15 piantan dengan koordinat $6^{\circ}$ 51' 33" Lintang Selatan dan $109^{\circ} 41^{\prime}$ 53" Bujur Timur. Penentuan pola pasang surut dilakukan dengan menggunakan komponen pasang surut, selanjutnya dari komponen tersebut dilakukan perhitungan nilai formzhal. Berikut ini adalah nilai komponen pasang surut yang didapatkan dari hasil pengolahan data disajikan pada tabel berikut ini:

Tabel 2. Komponen Pasang Surut Juni 2020

\begin{tabular}{ccc}
\hline $\mathbf{C m}$ & $\mathbf{A}$ & $\mathbf{g}^{\mathbf{0}}$ \\
\hline S0 & 163,83 & 0 \\
\hline M2 & 8,04 & 325,82 \\
\hline S2 & 4,70 & 157,59 \\
\hline N2 & 30,05 & 535,91 \\
\hline K1 & 9,61 & 1,24 \\
\hline O1 & 9,67 & 185,13 \\
\hline M4 & 2,41 & 659,20 \\
\hline MS4 & 3,44 & 163,60 \\
\hline K2 & 1,27 & 157,59 \\
\hline P1 & 3,17 & 1,24
\end{tabular}

Berdasarkan hasil perhitungan menggunakan RBR Tidelogger, didapatkan nilai formzhal sebesar 1,05. Nilai formzhal tersebut dengan tipe pasang surut campuran condong harian tunggal dikarenakan nilai $f<3$. Secara umum, pasang surut campuran condong harian tunggal Merupakan pasang surut tipe campuran yang dominan terjadi 1 kali pasang dan 1 kali surut dalam sehari. Berdasarkan pengolahan data pasang surut juga, didapatkan nilai dengan tipe pasang surut campuran condong harian tunggal dengan nilai MSL sebesar $163.84 \mathrm{~cm}$. Nilai HHWL sebesar $236.18 \mathrm{~cm}$, dan nilai LLWL sebesar $99.52 \mathrm{~cm}$. Hal ini menandakan bahwa tipe pasut pada perairan TPI Wonokerto memiliki tipe pasut campuran dengan tunggal yang lebih dominan. Hal ini ditandai dengan terjadinya satu kali pasang dan satu kali surut namun kadang-kadang terjadi dua kali pasang dan dua kali surut dengan tinggi dan periode yang berbeda. 


\section{Pasang Surut Menggunakan Metode Worldtides}

Pada pengolahan pasang surut dengan metode Worldtides dengan menggunakan aplikasi Matlab 2014 didapatkan nilai Amplitudo dari setiap komponen pasang surut yakni adalah O1 P1 K1 N2 M2 S2 K2 MS4 dan K4. Nilai amplitudo pada setiap komponen pasang surut adalah sebagai berikut:

Tabel 2. Nilai Komponen Pasang Surut menggunakan Metode Admiralty

\begin{tabular}{ccc}
\hline $\mathbf{C m}$ & $\mathbf{A}$ & $\mathbf{g}^{\mathbf{0}}$ \\
\hline S0 & 164 & 0 \\
M2 & 7,1 & 230,38 \\
S2 & 17,9 & 100,31 \\
N2 & 5,2 & 81,05 \\
K1 & 18,60 & 1344,44 \\
O1 & 3,7 & 155,09 \\
M4 & 0,04 & 312 \\
MS4 & 0,04 & 93,76 \\
K2 & 14,3 & 242,53 \\
P1 & 5,5 & 34,92 \\
S4 & 0,2 & 350,09
\end{tabular}

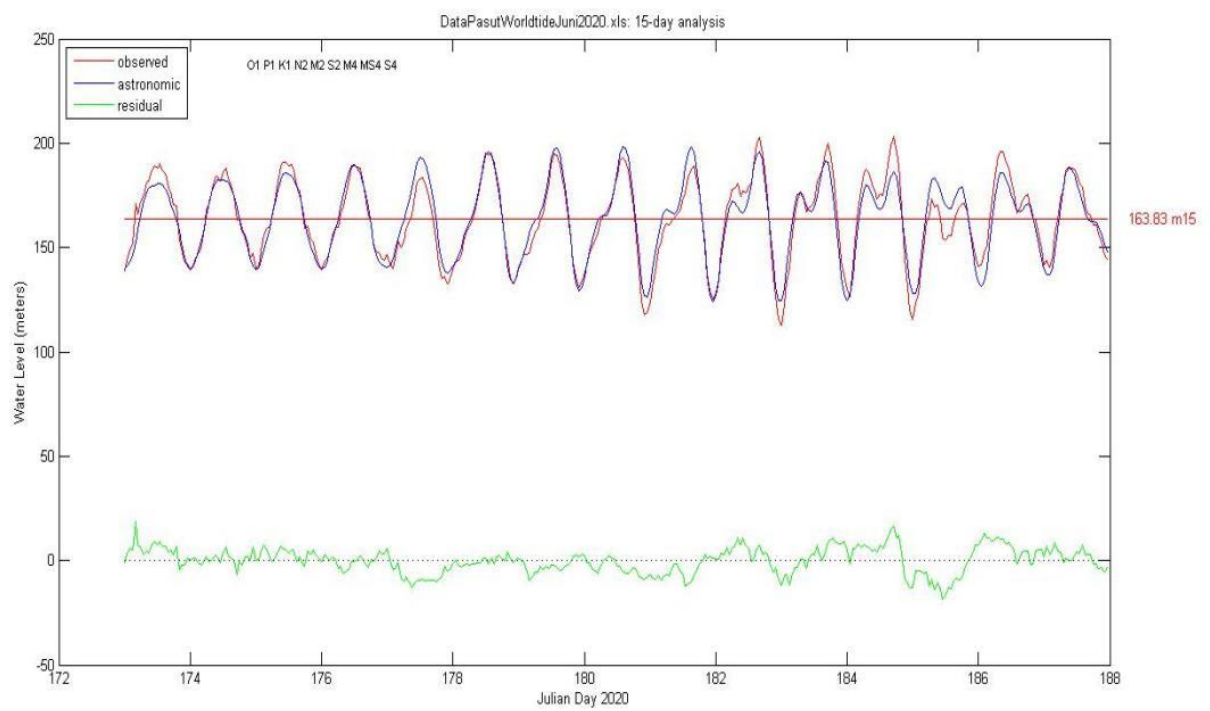

Gambar 1. Grafik Perbandingan Antara Data Pasang Surut Lapangan Dengan Peramalan Pasang Surut Menggunakan Metode World Tide.

Peramalan pasang surut dengan metode Worldtide didapatkan elevasi pasang surut selama 5 tahun kemudian diperoleh nilai LWL dan HWL pada tiap bulan selama kurun waktu 5 tahun tersebut. Nilai HWL pada tahun 2022 sampai 2026 adalah pada bulan Oktober 2025 sebesar $225 \mathrm{~cm}$. Sedangkan nilai LWL terjadi pada bulan Agustus 2026 sebesar $105 \mathrm{~cm}$. Perbedaan nilai elevasi 
pasang surut ini disebabkan oleh faktor astronomis gaya tarik matahari, bumi dan bulan yang berubah secara periodik dan juga karena tipe pasang surut di Muara TPI Wonokerto adalah campuran condong harian tunggal oleh sebab itu perubahan disebabkan oleh deklinasi bulan.

Tabel 3. Nilai HHWL Tertinggi dan LLWL terendah pada Tiap Tahunnya menggunakan Metode Worldtides

\begin{tabular}{ccccc}
\hline \multicolumn{5}{c}{ Worldtides } \\
\hline Wahun & Bulan & HHWL & Bulan & LLWL \\
\hline 2022 & April & 223.79 & Agustus & 106.9 \\
\hline 2023 & April & 224.46 & Februari & 105.32 \\
\hline 2024 & April & 223.77 & Februari & 105.18 \\
\hline 2025 & Oktober & 224.6 & Agustus & 106.35 \\
\hline 2026 & Maret & 224.53 & Agustus & 104.99 \\
\hline
\end{tabular}

\section{Analisis Kolam Pelabuhan}

Berdasarkan pengukuran kedalaman yang telah dilakukan menggunakan single beam echosounder diperoleh data kedalaman terkoreksi terhadap muka air surut terendah atau LLWL pada perairan TPI Wonokerto berkisar antara 2,1 meter hingga 3 meter. Kedalaman pada TPI Wonokerto ditampilkan pada gambar berikut:
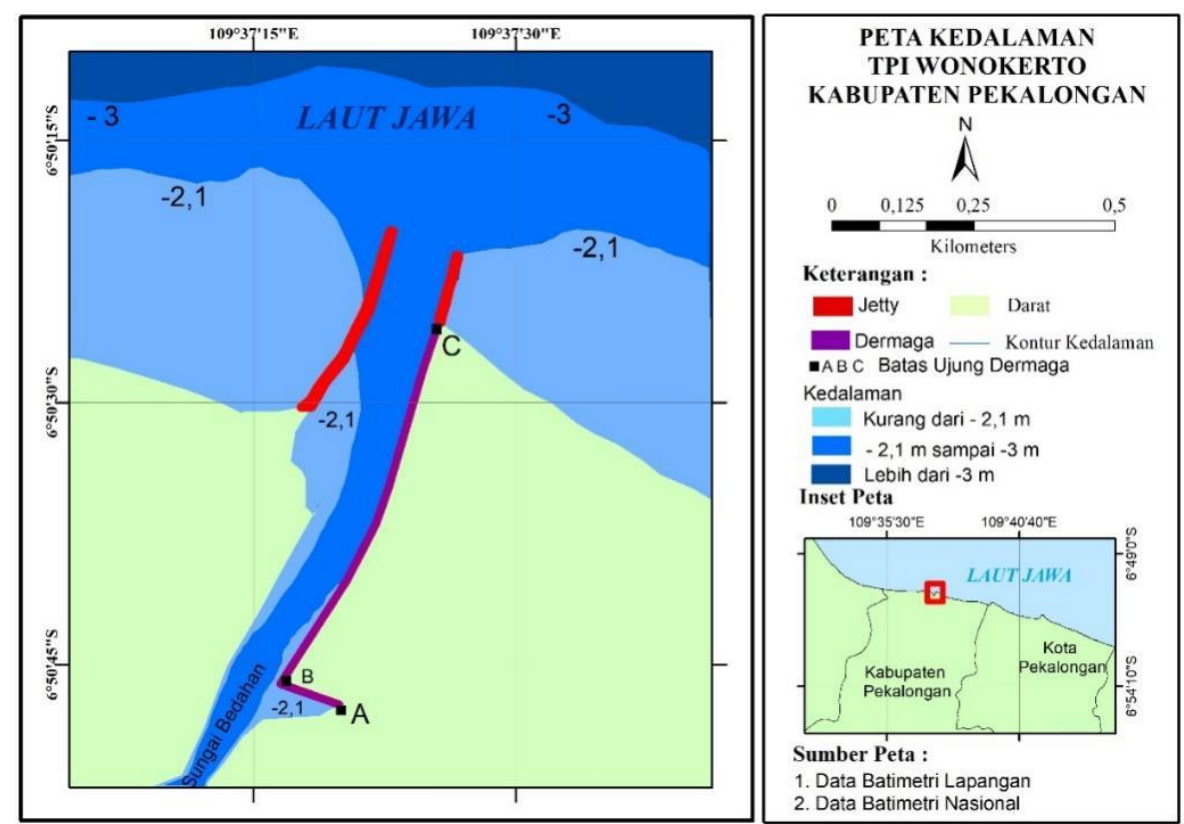

Gambar 2. Peta Kedalaman TPI Wonokerto

Menurut Dinas Kelautan Perikanan Kab. Pekalongan bobot kapal ikan yang digunakan oleh nelayan sebesar 3 GT dan 5 GT, dengan bobot kapal ikan terberat yang pernah bersandar di TPI wonokerto memiliki bobot sebesar $10 \mathrm{GT}$ dan pernah bersandar dermaga pada titik C. Oleh karena itu, perhitungan kedalaman kolam pelabuhan yang aman untuk kapal bersandar mengacu pada bobot kapal yang bersandar yaitu 10 GT. Berdasarkan perhitungan kedalaman kolam pelabuhan untuk kapal 
yang aman dengan bobot kapal 10 GT didapatkan nilai sebesar 2,05 meter. Kedalaman kolom Pelabuhan yang terukur di TPI Wonokerto berkisar dari 2,1 meter hingga 3 meter sedangkan pada area laut berkisar hingga 3,6 meter. Analisis kolam pelabuhan merupakan analisis yang diperlukan untuk melihat apakah perairan tersebut cukup aman untuk dijadikan dermaga dan untuk mengetahui dermaga tersebut layak untuk menjadi tempat sandar dari kapal. Menurut informasi dari Dinas Kelautan dan Perikanan Kabupaten Pekalongan, kapal terberat yang pernah merapat di perairan TPI Wonokerto, jenis muatannya $10 \mathrm{GT}$, dan klasifikasi draft $105 \mathrm{~cm}$. Berdasarkan perhitung kedalaman kolam pelabuhan yang aman untuk kapal ikan yang berbobot 10 GT adalah 2,05 meter.

Kedalaman kolam pelabuhan TPI Wonokerto aman untuk kapal nelayan yang bersandar dengan bobot maksimal 10 GT, hal ini dikarenakan kedalaman kolam pelabuhan yang terukur lebih besar dari pada batas aman kedalaman, pada gambar 7 diperlihatkan bahwa titik $\mathrm{C}$ memiliki kedalaman sedalam 3 meter, menurut informasi Dinas Kelautan dan Perikanan Kab. Pekalongan kapal berbobot 10 GT pernah bersandar di area tersebut. Pada saat surut terendah kapal berbobot 10 GT tidak dapat bersandar pada titik A dan B dikarenakan pada titik A dan B memiliki kedalaman sebesar 2,1 meter, pada kedua titik tersebut merupakan tempat bersandar dari kapal nelayan berbobot 3 GT hingga 5 GT.

\section{Ketinggian Lantai Dermaga}

Berdasarkan perhitungan kolam dermaga menggunakan data hasil pengolahan pasang surut dan data kedalaman air rencana. Data pasang surut yang diolah menggunakan metode Admiralty berupa HHWL yang telah ditambahkan dengan nilai Clearance menunjukan hasil $367 \mathrm{~cm}$. Data peramalan pasang surut menggunakan World Tides juga dihitung dengan cara melihat HHWL tertinggi selama masa peramalan 5 tahun dan kemudian ditambahkan dengan nilai Clearance menunjukan hasil $374 \mathrm{~cm}$ untuk metode World Tides. Nilai Clearance pada perairan TPI Wonokerto sendiri memiliki nilai sebesar $150 \mathrm{~cm}$. Nilai HHWL dapat dilihat pada tabel berikut.

Tabel 4. Nilai HHWL Dari Kedua Metode Pada Tahun 2020

\begin{tabular}{ccc}
\hline \multirow{2}{*}{ Nilai } & \multicolumn{3}{c}{ Metode } \\
\cline { 2 - 3 } & Admiralty & Worldtide \\
\hline MSL & 164 & 164 \\
\hline HHWL & 218 & 223 \\
\hline
\end{tabular}

Pada nilai HHWL sebesar $218 \mathrm{~cm}$ yang diolah menggunakan metode Admiralty, tinggi lantai dermaga dianggap aman dan tidak akan mengalami kejadian terendam oleh perairan karena pada saat keadaan pasang tertinggi lantai dermaga masih berada diatas perairan dan memiliki nilai jeda dengan permukaan perairan setinggi $33 \mathrm{~cm}$. Pada analisis ketinggian lantai dermaga pada nilai peramalan tinggi HHWL tertinggi selama 5 tahun menggunakan metode Worldtides yang menunjukan nilai sebesar $223 \mathrm{~cm}$, kapal masih dianggap aman untuk bersandar di perairan TPI Wonokerto karena pada saat pasang tertinggi lantai dermaga masih memiliki jeda dengan permukaan perairan setinggi $26 \mathrm{~cm}$.

\section{KESIMPULAN}

1. Perairan TPI Wonokerto memiliki tipe pasang surut dengan tipe pasang surut harian berupa campuran condong harian tunggal, dengan nilai formzhal sebesar 1.51. Peramalan pasang surut dengan metode World Tides selama 5 tahun menunjukan bahwa HHWL tertinggi terjadi pada bulan Maret tahun 2026 dengan ketinggian 224,53 cm dan LLWL terendah terjadi pada bulan Agustus tahun 2026 dengan ketinggian 104,99 cm. 
2. Kedalaman kolam pelabuhan yang ideal pada saat surut terendah atau LLWL yakni $2,05 \mathrm{~m}$ sehingga cukup aman untuk kapal nelayan bersandar dengan bobot hingga $10 \mathrm{GT}$

3. Analisis ketinggian lantai dermaga menunjukan nilai jeda antara permukaan air pada saat HHWL dengan ketinggian lantai dermaga yang sudah ada sebesar $33 \mathrm{~cm}$ untuk metode Admiralty dan $26 \mathrm{~cm}$ untuk metode World Tides. Ketinggian lantai dermaga pada dermaga perairan TPI Wonokerto dianggaap aman dan cukup ideal untuk tempat kapal bersandar.

\section{DAFTAR PUSTAKA}

Dinas Kelautan, Perikanan dan Peternakan. 2015. Review Total Desain TPI Wonokerto. DPPKP, Pekalongan.

Poerbandono dan E. Djunarsjah, 2005. Survei Hidrografi. Refika Aditama, Bandung. 166 hlm.

Mustofa R N, Mudzakir K A dan Kurohman F. 2018. Pengembangan Berbasis Komoditas Unggulan Perikanan Tangkap di Kabupaten Pekalongan. Jurnal Perikanan,7 (2) : 68-77

Sugiyono, 2006. Metode Penelitian Kuantitatif Kualitatif dan R\&D. CV Alfabeta, Bandung. 380 hlm.

Triatmodjo, B. 1999. Teknik Pantai. Beta Offset, Yogyakarta. $130 \mathrm{hlm}$.

Triatmodjo, B. 1999. Perencanaan Pelabuhan. Beta Offset, Yogyakarta.

Wijaya I , Setiyono H, Warsito Atmojo. (2017). Karaketeristik Pasang Surut dan Kedudukan Muka Air Laut di Perairan Pangkalan Pendaratan Ikan (PPI) Campurejo Kabupaten Gresik. Jurnal Oseanografi. 6 (1): $151-157$ 